\title{
A CASE OF PRIMARY CANCER OF THE FRONTAL SINUS
}

\author{
$\mathrm{By}$ \\ T. KOBAYASHI
}

From the Department of Oto-Rhino-Laryngology, Nagasaki University, Schoo! of Medicine

(Director: Prof. T. Goto)

This is a case report of a 53 year old male with primary carcinoma of the frontal sinus in a 53 years old male.

The tumor was localized in the frontal sinus. The preoperative diagnosis was possible muco. cele.

A radical extranasal operation was cerried out successfully. The patient has shown no signs of recurrence for one year.

\section{原発性前頭洞癌の 1 例}

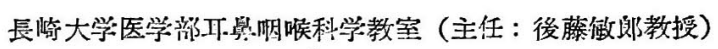

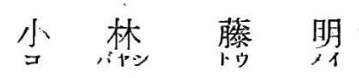

緒言

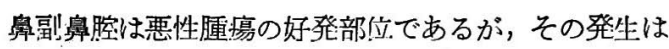
殆えど上頡洞に限られ他の副鼻腔に見られることは極め て稀である・著者讨最近前頭洞 mucocele の診断のる とに手術を行い，その結:果原発:性前頭洞癌であることを 碳認したので稀有な例として報告する・

症例 西○義 $\bigcirc 53$ 于，男子，初診 昭和 33 年 1 月 11 日・主訴 左上眼臉の腫脹, 家族䄳では父の異母兄 弟中 1 名が胃癌で死亡した他は特記すべきものはない。 既往歷には著患を知らない(第 1 図).

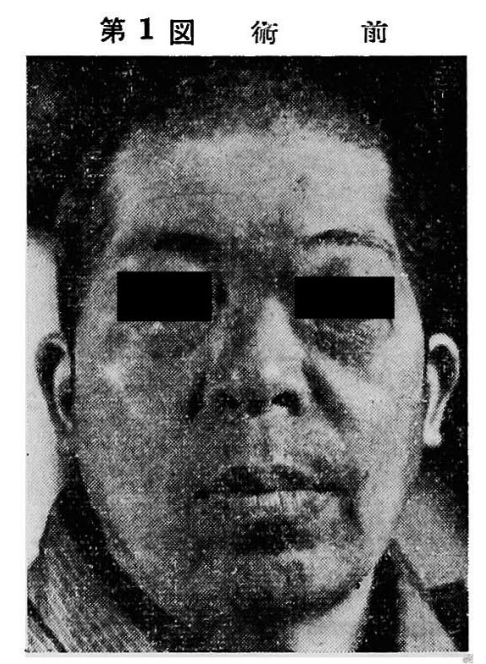

炤和 30 个:の秋に 左下眼臉に大豆大の 連脹のあるのに 気付いた・当時眼科医を訪れたが診断未定のま小経過し ていたが 32 年 5 月に腫脹が 幾分か増大したように思わ れたので眼科医の切開を受けた・この切開創は䐓藅に治 㗧した・ 32 年 9 月に再び 同一部立の腄脹をきたしたの で再切開を受けたがその後下眼瞼には異常は見られな ‥ 32 年 11 月中旬に左上腿瞼に腫脹が起つたが放置し たま〉翌 33 年 1 月 11 日当科を訪れた・

全身所見は体格中等で栄養は良好, 血液像气の他偣

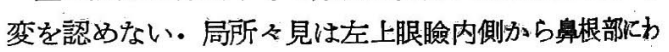
たつて軽度の腫脹があり, 色調は正常で圧痛はなく, 强 性や〉硬である・耳腔は両側共に全く異常がなく，瑔 写真では上顎洞，篩骨洞には良好な発育が見られるか病 的陰影は認められない. 眼球運動は正常で眼球突出位 右 $21 \mathrm{~mm}$, 左 $24 \mathrm{~mm}$ (nach Hertel) である. 梘加 右 $0.1(0.3 \times-8.0 \mathrm{D})$, 左 $0.1(0.3 \times-5.0 \mathrm{D})$, 梘影蚛 両側共に軽度の求心性視野狭窄が認められる・眼底性軽 度の豹絞状を示しや人著明な下方コーヌスを証める他 には特に变化は認められない. 以上の所見から前顠间 mucocele の診断のもとに手術を行つた。

手術所見 型の如く上罰洞，篩骨洞を開いてみるに， 上顎洞は容積大で洞粘漠は節骨洞との境界部分で一部 腫性の腫脹が見られる他は全く正常で，天蓋に近い部分 の粘膜は皺壁を形成して中隔状に突出している・骨暨沬 
正常である・薛骨洞は骨側に小蜂䆞があり粘脱は軽度に 惂脤している・ 又との側方眼简との間にくるみ大の大峰 㮤がありその粘漠は正常で鼻腟との交通が認められる。 以上の峰窠の後方に大きい洞が 2 個あり，その後方のも のは挪状洞之思われるが粘膛はこの洞のみや〉蕾脹して いる. 但し内容は空であつた・篩骨洞の前群は大小数個 あり，何れも粘膜には腫脹が認められ，一部に粘稠な粘 液を入れているるのもある・更に前上方を鉗除するとや や硬い肉苯状のものを得たがこれは前頭洞に相当する部 分と思われた。一方眉毛切閭法によつて前頭洞を開い た・その前下壁は融の吸収が認められ，中に大きな洞が

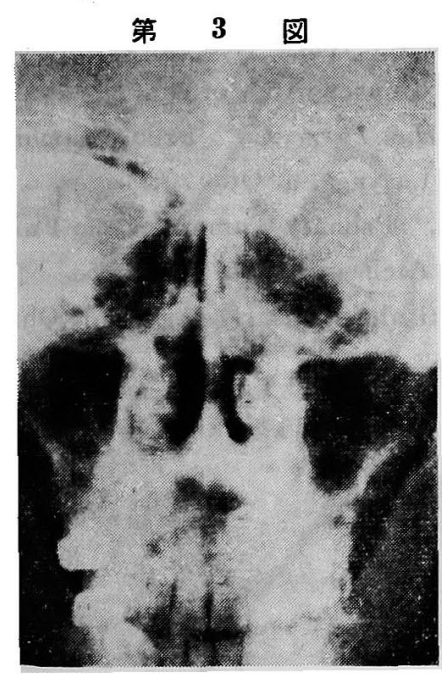

あつて浮嘴状の肉第様の組織でみたされている・分泌液 の渚留は認められない.眼墖壁にも一部に骨の吸収が諗 められた・よつて充分に肉等様組織と一部残存の洞粘湟 を除去したのち前頭洞には細いガービタンポン1本を插 入して 2 針縫合を行い，上顎洞には広い対孔を作りガー

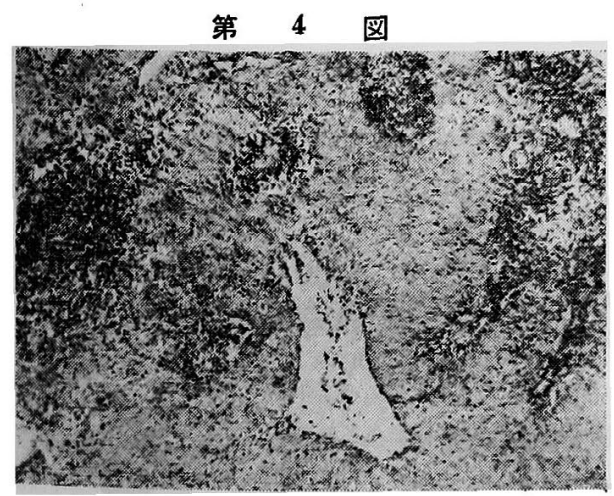

ゼタンポンを施して術を終つた。

肉芽の組䋨検查の結:果扁平上皮癌を磪認した'符4,5図)

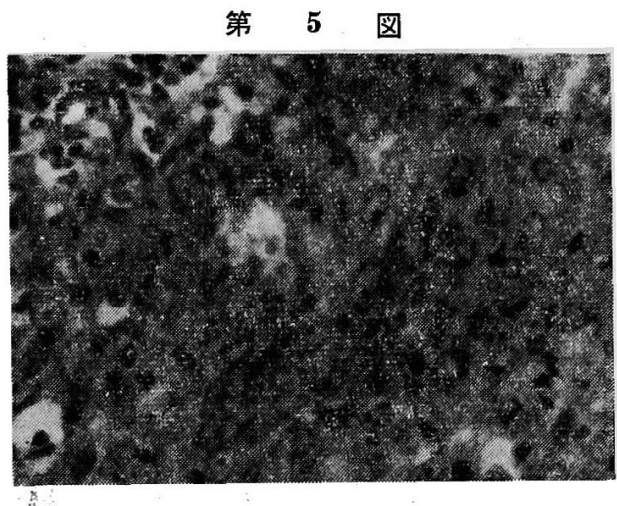

術後の全身状態は良好で術創の治瘉も順調に経過して 術後 14 日目に限院せしめた・一少術後3 日目よりレ線

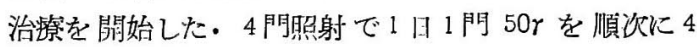
阴まで 4 日間連繶して照射し，その後 3 日間を休み，か くして 1 週 200r宛第 7 週まで照射した・乘に 4 週間の 休みの後第 2 回目のレ線治拪:を行い総星 2800 子を照射 した・その後は何等の处犆も施すことはなく経過を観祭 中であるか゚, 術後約1为年を経過した今日, 全身局所共 になん等の異常も認めず健康体として芜業に励んでい る(簀 2 図)。

第 2 図街後 1 年

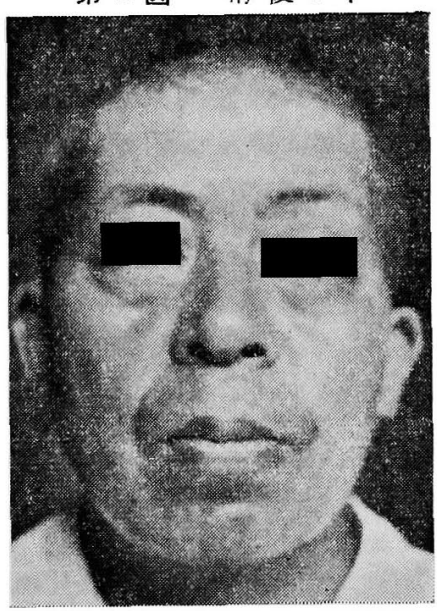

考按

原発性前頭洞癌は非常に稀な疾患で，本邦での龂告例 は管井他（1956）の竍告就よび佐滕他（1958）の郝告と 統計によると，伊積の報告 (1924) 以来19 例とされてい 
る・しかも前頭洞癌の予後が極めて悪い事は一般の認め る所であつて，本症の報告例の大多数が早期に死の転帰

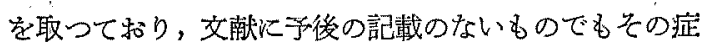

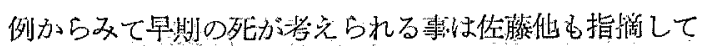
いる通りである・この事寒は要するに他の領域に拉ける 癌の場合之同樣に早期発見が困難である事以上るもの で,このために㤢藤他る手術可能時期には診断が不可能 であり，䛦断が磪定する頃には手術が不可能であるから 前頭洞癌と関する限り，手術はさけてレ線治療を原則と すべきであると述べているが，本症例からかえりみて頭 蓋底えの侵晸が見られない時期の前頭洞癌では，その予 後にはかなりに良い結果が期待できる上らに思かれる。

\section{結語}

原登性前頭洞癌に手術を行い，良好な経過を抝り口つ ある1例を報告した・

\section{文、献}

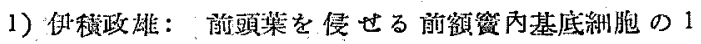
例，日耳耳幖，30；1，85，1924. 2) 松田能一：前額蜜 に原発したる府本上皮細胞痁缠の1 例，日耳莮，31；6，

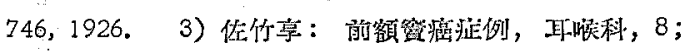

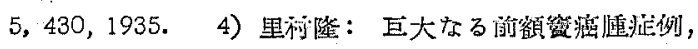
耳薙科，11；6，521，1938. 5) 斎藤一郎：前頭洞憈

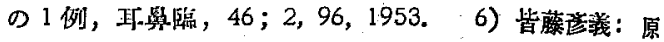

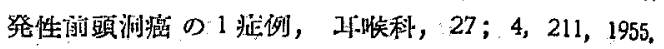

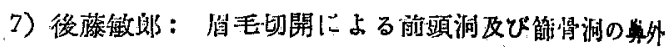

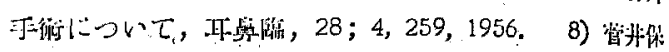

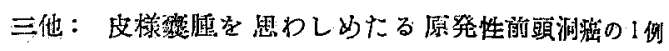

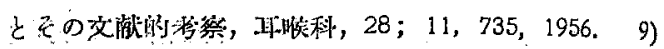

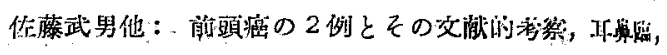

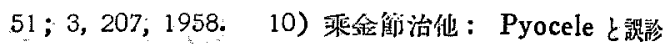

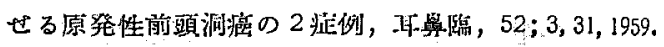
11) Sciarra, $P_{.} \&$ Hallberg, E.: Primary Squam. ous Cell Carcinoma of the Frontal Sinus. Ann. O. Oto. $65 ; 225,1956.1$ 12) Breeding, E.: Malig. nancy of the Nasal Accessory Sinuses with the Frontal Sinuses. Ann. o. Oto. 49; 141, 1940. 13) Rainer, H.\& Eurne, C.; Front-Ethmoidal Carcinoma. J. Laryngo, a. Oto. 70; 420, 1956. 14) Bru. nner, $H_{\text {:: }}$ Primary Tumors of the Frontal Bone. A.M.A. Arch. o. Oto. 57 ; 158, 1953 . 15) R. Kosc. hier: Stirnhoehlensarkom. Mschr. Ohrenheilkun. de $85 ; 69,1951$.

（原稿到着＝昭和 34.4.3 日)： 